\title{
Incoming NSF director faces challenges in Congress
}

\section{Former Purdue University president France Córdova inherits an agency at a crossroads.}

\section{BY JESSICA MORRISON}

$\mathrm{B}$ $y$ all accounts, astrophysicist France Córdova thrives in the face of a challenge. As NASA's chief scientist in the mid-1990s, she helped then-administrator Daniel Goldin to push his 'faster, better, cheaper' vision for space research. Later, as chancellor of the University of California, Riverside, she won approval for a long-sought medical school. And during her 2007-12 tenure as president of Purdue University, she helped to double research funding despite a global recession.

That persistence should serve her well as director of the US National Science Foundation (NSF), the position she assumed after her appointment was confirmed by the Senate on 12 March. The US\$7.2-billion agency, which funds basic non-medical research, has seen its budget stagnate in recent years and is now facing attacks on its peer-review system

$\stackrel{\infty}{\gtrless}$ and social-science division from conservative members of Congress.

"The toughest challenge that she's facing right now is one that is faced by all of the research institutions that are funded by taxpayer dollars - relevance," says Internet pioneer Vinton Cerf, vice-president of Google and a member of the National Science Board, which oversees the NSF.

\section{POLITICAL EXPERIENCE}

Córdova studied English at Stanford University in California, and received a physics doctorate from the California Institute of Technology in Pasadena in 1979. She then spent a decade at Los Alamos National Laboratory in New Mexico, studying X-ray and $\gamma$-ray sources, before making her first foray into administration at Pennsylvania State University in University Park, where she served as head of the astronomy department from 1989 to 1993 . Her subsequent moves to NASA, the University of California, Riverside, and Purdue in West Lafayette, Indiana, saw her take on positions of increasing responsibility.

Córdova is no stranger to the NSF or its struggles. Until her confirmation, she was a member of the National Science Board, and chaired the governing board of the Smithsonian Institution in Washington DC, the world's largest museum complex. Her time on the science board is likely to shorten her learning

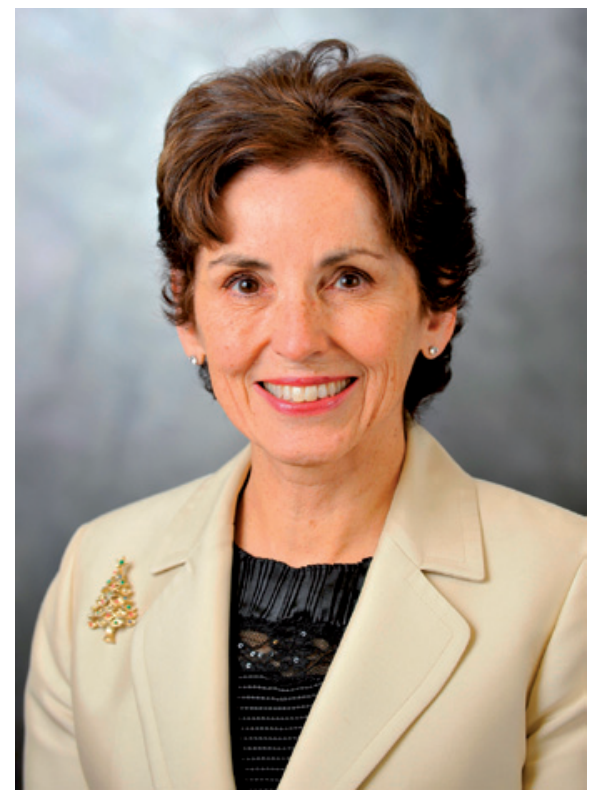

France Córdova became head of the National Science Foundation on 12 March.

curve as she assumes the NSF's top job, says environmental microbiologist Rita Colwell, who led the agency from 1998 to 2004.

Goldin, now chief executive of the Intellisis Corporation in San Diego, California, says that Córdova has already proved her ability to operate in the thorny political environment of Washington DC. At NASA - her first government post - she was pivotal to implementing Goldin's controversial plan to expand the agency's scientific reach and stretch its budget by backing smaller, less expensive science and exploration missions. "She developed really good, solid relationships with staff in the House and Senate, and the White House," he says. "She is able to communicate with people on the issues and not emotions."

That experience, and her subsequent work as a university administrator, is not far from Córdova's mind as she assumes her new role. "I don't feel like I've ever left government," she told reporters the day after her Senate confirmation. "I've been involved in one way or another - taking money or giving it."

With austerity a priority in Washington DC, Córdova is already thinking about how to make the NSF's research dollars go further. "Budgets are limited, and that's always a challenge,"

she tells Nature. "But I think that government organizations like NSF could work toward more partnerships with industry, foundations and private donors, to leverage the amount of money that each has."

\section{CONGRESSIONAL CAMPAIGN}

Córdova has a long-term goal to further the foundation's emphasis on interdisciplinary and international research programmes - a focus of her immediate predecessor as NSF director, engineer Subra Suresh, who resigned a little over a year ago. But she also faces a more immediate challenge: winning over some of her agency's staunchest critics, members of Congress who are questioning the quality of the research that the NSF supports.

On 10 March, Republican members of the House of Representatives' science committee introduced a bill that would require the NSF to certify each grant it awards as serving the "national interest" in one of six categories (see Nature http://doi.org/rxg; 2013). The bill, put forward by congressmen Lamar Smith (Republican, Texas) and Larry Bucshon (Republican, Indiana), also seeks to slash funding for the NSF's social-science directorate by $22 \%$, to $\$ 200$ million, while increasing spending on many of the agency's other major research divisions. That would commit more of the NSF's limited funds to producing discoveries that drive economic

"We have to better explain why we do what we do." ple sentiment that Córdova heard over and over again in recent weeks as she spent time getting to know key members of Congress and their aides while waiting for the Senate to confirm her new post. "We have to better explain why we do what we do," she says of the NSF.

Córdova's operating style may be just what is needed to get the message across. Former colleagues say that she draws on her diplomacy and innate curiosity to build a broad base of support for her goals. "She surrounds herself with clear thinkers, and she solicits their opinions," says Philip Low, a chemist who directs Purdue's Center for Drug Discovery. "No one is the sole repository of wisdom, and she recognizes that." - 